\title{
Role of Panchayati Raj Institutions in Rural Development: An Analytical Study of Arunachal Pradesh
}

\author{
Tabang Mibang ${ }^{1}$ and Kamin Modi ${ }^{2}$ \\ ${ }^{2}$ Research Scholar, ${ }^{1 \& 2}$ Department of Political Science, \\ Rajiv Gandhi University, Doimukh, Arunachal Pradesh, India \\ E-Mail: mibang22@gmail.com
}

\begin{abstract}
Rural Development is viewed as strategy to bring improvement in the economic, political and social life of the rural people. The participation of people in rural development is a must because the developmental activities have to be carried out by the government along with their cooperation. The local government is considered as an instrument of development and welfare programmes. The full benefit of democracy can be realized only when there is true devolution of both power and resources down to the grassroots. Arunachal Pradesh, predominantly a tribal state with more than 26 major tribes and several dozen of minor groups fulfilled the constitutional requirement of institutional arrangement for decentralisation with formulation of Arunachal Pradesh Panchayati Raj Act, 1997 by replacing the NEFA (North Eastern Frontier Agency) Panchayati Raj Regulation, 1967. However, people still suffer from socioeconomic backwardness and yet to reap the benefit of devolution of power to the people. Hence, the study is an attempt to analyse the role of panchayati raj institutions in rural development and perception of the rural locals in three districts of Arunachal Pradesh.

Keywords: Decentralisation, Panchayati Raj System, Seventy Third Constitutional Amendment, Local Governance, Rural Development
\end{abstract}

\section{INTRODUCTION}

The problems as well as the achievements of development have been subjected to a good deal of academic scrutiny in recent times. Developmental studies which was almost exclusively concerned with economic issues and its growth strategy to raise the levels of living of the masses is now paying attention to the multiple dimension of the development (Jalihal \& Shivamurthy: 2003). In the present context, it is not mere development but sustainable development which enables people towards empowerment. In this regard, rural development is a concern of special attention to enable development at the grass root level. Robert Chambers defines rural development as a strategy to enable a specific group of people, poor rural women and men, to gain for themselves and their children more of what they want and need. It involves helping the poorest among those who seek a livelihood in the rural areas to demand and control more of benefits of rural development (Chambers: 1983). Uma Lele defines rural development as improvement in the living standard of the masses of low income population, residing in rural areas and making process of self-sustaining (Lele: 1975). Hence, rural development encompasses the process of improving the living condition of the rural masses by providing minimum needs, increasing productivity and opportunity to use local resources with the objectives to improve the quality of rural people. As a phenomenon, rural development is the end-result of interactions between various physical, technological, economic, social, cultural and institutional factors (Mathur: 1996). Rural Development is a multidimensional concept which encompasses the development of agriculture and allied activities, village and cottage industries and crafts, socio-economic infrastructures, community services and facilities and, above all, human resources in rural areas. As a strategy it is designed to improve the economic and social well-being of a specific group of people, the rural poor. As a discipline, it is multi-disciplinary in nature, representing an inter-section of agriculture, social, behavioural, engineering and management sciences (Singh: 1999)

The primary concern of rural development is to increase the availability and improve the distribution of lifesustaining goods, such as food, clothes, shelter, health and security; to raise per capita purchasing power and improve its distributions by providing better education, productive and remunerative jobs and cultural amenities; and to expand the range of economic and social choices to individuals by freeing them from servitude and dependence (Desai: 1991). Taking into account the different dimensions, it can be analysed that Rural Development is a process which aims to raise the capacity of people so that they could control their environment within the distribution of benefits (Mishra, Akhtar and Tarika: 2011). In brief, it is viewed as strategy to bring about improvement in the economic, political and social life of the rural people. The participation of people in rural development is a must because the developmental activities have to be carried out by the government along with their cooperation. The local government is considered as an instrument of the implementing machinery of the state development and welfare programmes, and as a unit of government at the local levels. Panchayati Raj system serves the most effective forms of local governments available where the people can participate meaningfully (Maheswari: 2000). The full benefit of 
democracy can be realized only when there is true devolution of both power and resources down to the grass root.

\section{PANCHAYATI RAJ INSTITUTIONS}

India, with about seventy to eighty percent of rural population, gave priority to rural development right from the time of independence. The Government of India in an attempt to bring about changes in socio-economic conditions of rural poor, made several efforts in the economic planning, policy formulations and implementation of multiple policy prescriptions (Swain 2008). Introduction of Community Development Programme in October, 1952 and National Extension Service in 1953 happened to be a concerted effort in this direction (Mishra \& Mishra: 2002). It introduced Community Development on wider scale, encompassing almost all activities of rural development to facilitate self help efforts to the locals through participation. The efforts undertaken through these programmes in different parts of the country have been varied in nature and the impact in most of the areas has been quite disappointing. As a result there has been a paradigm shift. The erstwhile emphasis on top-down approach got replaced by bottom-up emphasis. It was realized that, it would be difficult to achieve broad based rural development without adequate involvement of the people at grassroots level in formulating and implementing various programmes for their socio - economic upliftment (Maheswari: 2000). It got translated into policy intervention for creation of space for the locals to have share not only in policy formulation but also in the implementation of the same. A major milestone in this direction was achieved when the parliament passed the $73^{\text {rd }}$ Constitutional Amendment Bill, in 1992.

\section{PANCHAYATI RAJ INSTITUTIONS IN ARUNACHAL PRADESH}

Arunachal Pradesh, though politically a nascent state is the only hill state in North East region which introduced Panchayati Raj Institutions as early as 1969 under the North-Eastern Frontier Agency (NEFA) Panchayati Raj Regulation, 1967. Like the rest of the country, Panchayati Raj Institutions in Arunachal Pradesh aimed at democratic decentralization of power and implementation of developmental programmes at the grassroot level (Talukdar: 1987). The introduction of statutory Panchayat in Arunachal Pradesh ended the policy based on interference - non interference dichotomy of early years and ushered in uniform political practice throughout the territory on national model by introducing an integrated political system. With the coming of the 73rd Amendment Act, 1992, the government of Arunachal Pradesh amended the existing NEFA Panchayati Raj Regulation of 1967 by promulgating an ordinance on $18^{\text {th }}$ April, 1994 (Dubey: 2005). The Bill was returned for some minor modification. However, with the amendment of new State Act, the Bill received the assent of the president of India and promulgated to Arunachal Pradesh Panchayati Raj Act, 1997 by replacing the NEFA (North Eastern Frontier Agency) Panchayati Raj Regulation, 1967.

The Act hailed important landmarks in conformation with Seventy Third Amendment Act in democratic decentralization, devolution of power, financial autonomy and provided space for participation of women and marginalized sections in the decision making process at grassrooot level (Gyati: 2012). Hence, it is quite relevant to investigate the mechanism of positive corelation between the rural people and rural development, evaluate both quantitative and qualitative measures of rural development and to identify institutional, structural and physical disabilities of effective control, monitoring and evaluation of rural development. Constitutionally, the Panchayats have been recognised with wide powers and associated with two broad images - as government by itself and an agency of the state government through which developmental schemes are implemented. In the integrated exercise of planning for social and economic development, the Panchayati Raj Institutions is a three-tier representative structure of government where the administrators, elected leaders and local population participate in the developmental effort (Thanikasalam \& Saraswathy: 2014).

\section{OBJECTIVES OF THE STUDY}

The objectives of the study are

1. To understand people's perception about the role of panchayati raj institutions in rural development,

2. To examine participation of people in panchayati raj institutions.

\section{METHODOLOGY}

The study applies both historical and analytical method to understand both the historical background and the role of Panchayati Raj institutions in Arunachal Pradesh. The data for the study had been drawn both from primary and secondary sources. The primary data was collected through field survey by visiting the selected districts using interview schedule cum questionnaire and person to person interview with panchayat members, local intellectuals, common villagers and beneficiaries of different rural development schemes. For the secondary sources, study depends on various related documents, official acts, reports and records of Panchayat office. Both published and unpublished works are also used as secondary sources of data wherever possible. The data were analysed using a simple percentage computation.

The universe of the study constitutes Panchayati Raj institutions of three districts i.e., East Siang, Lower 
Subansiri and West Kameng districts of Arunachal Pradesh. The study have a sample size of 600 covering three panchayat blocks in each of the three districts (200 in each district) drawn from each panchayat block. The sample size of 200 respondents of different occupational group in each district were selected through random sampling for interview from each of the panchayat block of all the district to understand the popular perception of the panchayati Raj institutions and rural development in Arunachal Pradesh. For the purpose of the interview, suitably structured open ended interview schedule cum questionnaire for panchayat members and other occupational groups such as beneficiaries, local intellectuals, common villagers etc., were used for better understanding of the problems.

Rural Development is a process which aims to raise the capacity of the people so that they could control their environment within the distributions of benefits. The basic objective of rural development is to improve living conditions of rural masses that are living below poverty line and the rural area as a whole. It is a strategy to bring about improvement in economic and social life. Decentralisation is a step toward achievement of these objectives by advocating effective organisation of the people and brings them to the planning process. However it is being considered that rural masses are not involved in the planning process. As a result desired results are not achieved. Thus, taking this into perspectives a query was extended to the locals regarding role of Panchayati Raj institutions in Rural Development.
TABLE I PERCEPTION OF RESPONDENTS ON IMPORTANCE OF PANCHAYATI RAJ INSTITUTIONS

\begin{tabular}{|l|c|c|c|}
\hline \multirow{2}{*}{ Districts } & \multicolumn{2}{|c|}{$\begin{array}{c}\text { Do you think Panchayati } \\
\text { Raj Institutions are } \\
\text { beneficial for villagers? }\end{array}$} & \multirow{2}{*}{ Total } \\
\cline { 2 - 3 } & Yes & No & \\
\hline East Siang & $192(96.0 \%)$ & $8(4.0 \%)$ & $200(100.0 \%)$ \\
\hline Lower Subansiri & $196(98.0 \%)$ & $4(2.0 \%)$ & $200(100.0 \%)$ \\
\hline West Kameng & $184(92.0 \%)$ & $16(8.0 \%)$ & $200(100.0 \%)$ \\
\hline Total & $572(95.3 \%)$ & $28(4.7 \%)$ & $600(100.0 \%)$ \\
\hline
\end{tabular}

The table reveals that 95.3 per cent of the respondents considered Panchayati Raj Institutions as beneficial and contended it as effective while 4.7 per cent expressed dissatisfaction with the performance of Panchayati Raj Institutions. The respondents who responded 'No' reveals the problems such as working in lines of party, identifying the targeted group, party affiliation, etc, as the problems being faced in local panchayats. They also expressed dissatisfaction over the planning process and non involvement of the villagers in the process of policy formulation and implementation. The evaluation of the data above with regard to awareness of the villagers regarding panchayati raj institutions, however reveals that majority of the respondents are well aware about the function and role of panchayati raj institutions in rural development. They know the objective with which panchayats are instituted and the work they are to perform as the elected representative at the grass root level.

TABLE II PERCEPTION ON WORKING OF PANChayati RAJ INSTITUTIONS

\begin{tabular}{|l|c|c|c|c|}
\hline \multirow{2}{*}{ Districts } & Do you think Panchayati Raj Institutions are working in right direction? & \multirow{2}{*}{ Total } \\
\cline { 2 - 4 } & Yes & No & No response & $200(100.0 \%)$ \\
\hline East Siang & $56(28.0 \%)$ & $84(42.0 \%)$ & $60(30.0 \%)$ & $200(100.0 \%)$ \\
\hline Lower Subansiri & $60(30.0 \%)$ & $100(50.0 \%)$ & $40(20.0 \%)$ & $200(100.0 \%)$ \\
\hline West Kameng & $44(22.0 \%)$ & $100(50.0 \%)$ & $56(28.0 \%)$ & $600(100.0 \%)$ \\
\hline Total & $160(26.7 \%)$ & $284(47.3 \%)$ & $156(26.0 \%)$ & \multicolumn{2}{c|}{ Source: field survey } \\
\hline
\end{tabular}

The table clearly reveals that only 26.7 per cent of the total respondents responded that the Panchayati Raj Institutions in their district are functioning independently and working in right directions, while 47.3 per cent thinks that Panchayati Raj Institutions are not functioning independently and working in right directions as envisaged and 26 per cent don't have any answer to the questions.

On being discussed, they revealed the interference of political party at different level as major hindrances in attaining its objectives. Besides, lack of training of the panchayat members and lack of knowledge about different rural development schemes or programmes also contributed to inefficiency in policy implementation. Thus, the table distinctly shows that, majority of the respondents do not agree to the view that panchayati raj institutions are working independently.

This implies non adherence of the panchayat institutions to the guidelines as envisaged. This also implies ineffective and inefficient performance compromising accountability, transparency and participatory approach in implementation of rural development programmes. It was also found that majority of the respondents though well aware of the $73^{\text {rd }}$ constitutional amendment act do not know the technical problems associated with panchayat systems. 
TABLe III Perception On IMPLementation Of DeVelopmental Schemes

\begin{tabular}{|l|c|c|c|c|}
\hline \multirow{2}{*}{ Districts } & \multicolumn{2}{|c|}{ Do developmental schemes are successfully implemented in your area? } & \multirow{2}{*}{ Total } \\
\cline { 2 - 4 } & Yes & No & No response & $200(100.0 \%)$ \\
\hline East Siang & $76(38.0 \%)$ & $76(38.0 \%)$ & $48(24.0 \%)$ & $200(100.0 \%)$ \\
\hline Lower Subansiri & $60(30.0 \%)$ & $112(56.0 \%)$ & $28(14.0 \%)$ & $200(100.0 \%)$ \\
\hline West Kameng & $48(24.0 \%)$ & $112(56.0 \%)$ & $40(20.0 \%)$ & $600(100.0 \%)$ \\
\hline Total & $184(30.7 \%)$ & $300(50.0 \%)$ & $116(19.3 \%)$ & \multicolumn{2}{|c}{ Source: field survey } \\
\hline
\end{tabular}

In response to the querry, 30.7 per cent of the respondents responded that developmental schemes are being successfully implemented in their locality by panchayat members while 50.0 per cent opined that schemes are not successfully implemented by panchayat members and 19.3 per cent do not have answer with regard to the question. On being asked for the reasons, both panchayat and non panchayat respondents hold similar views and responded that beneficiaries are not identified and assisted based on criteria as provided in guidelines. It is because of the influence of the politicians and political party as they wanted that most of the benefit must go to their party members or their near and dear ones.

TABLE Iv PERCEPTION ON PERFORMANCE Of ELECTED REPRESENTATIVES OF PANCHAYATS

\begin{tabular}{|l|c|c|c|}
\hline \multirow{2}{*}{ Districts } & \multicolumn{2}{|c|}{$\begin{array}{c}\text { Do elected representatives } \\
\text { work for development of } \\
\text { your locality? }\end{array}$} & \multirow{2}{*}{ Total } \\
\cline { 2 - 3 } & Yes & No & \\
\hline East Siang & $72(36.0 \%)$ & $128(64.0 \%)$ & $200(100.0 \%)$ \\
\hline $\begin{array}{l}\text { Lower } \\
\text { Subansiri }\end{array}$ & $144(72.0 \%)$ & $56(28.0 \%)$ & $200(100.0 \%)$ \\
\hline $\begin{array}{l}\text { West } \\
\text { Kameng }\end{array}$ & $72(36.0 \%)$ & $128(64.0 \%)$ & $200(100.0 \%)$ \\
\hline Total & $288(48.0 \%)$ & $312(52.0 \%)$ & $600(100.0 \%)$ \\
\hline \multicolumn{3}{|c|}{ Source: field survey } \\
\hline
\end{tabular}

With regard to the query above, 48 per cent of the total respondents responded that elected representatives of panchayats effectively work for development of their locality while 52 per cent per cent hold the view that elected representatives of the panchayat do not effectively work for development of their locality.

There are various means through which participation of people in developmental activities are achieved. Developmental participation may be described as any voluntary act to influence public policy. It may be as simple as casting a ballot or running for office; it may be intended to influence the broad outlines of policy making and it may also be very specific. But intensity of developmental participation varies from individual to individual and from place to place. The intensity of developmental participation depends on several factors, but in rural areas it is solely dependent on the Panchayat institutions (Thanikasalam \&
Saraswathy: 2014). The importance of people's participation lies in view of long term effects of the process of modernisation. The planned intervention in this process is the sine qua non of integrated development.

Panchayat system is the simplest form of institution which ensures developmental participation at lowest level. It provides a peaceful mechanism for participation of people in the developmental activities of their locality. Hence, with regard to participation of the villagers in the developmental process, the respondents were asked certain quarries to assess their involvement.

TABle V Perception On Attendance In Panchayat MEetings

\begin{tabular}{|l|c|c|c|}
\hline \multirow{2}{*}{ Districts } & \multicolumn{2}{|c|}{$\begin{array}{c}\text { Do you attend Panchayat } \\
\text { meetings? }\end{array}$} & \multirow{2}{*}{ Total } \\
\cline { 2 - 3 } & Yes & No & \\
\hline East Siang & $92(46.0 \%)$ & $108(54.0 \%)$ & $200(100.0 \%)$ \\
\hline $\begin{array}{l}\text { Lower } \\
\text { Subansiri }\end{array}$ & $72(36.0 \%)$ & $128(64.0 \%)$ & $200(100.0 \%)$ \\
\hline $\begin{array}{l}\text { West } \\
\text { Kameng }\end{array}$ & $108(54.0 \%)$ & $92(46.0 \%)$ & $200(100.0 \%)$ \\
\hline Total & $272(45.3 \%)$ & $328(54.7 \%)$ & $600(100.0 \%)$ \\
\hline
\end{tabular}

The table above reveals that 45.3 per cent of the total respondents attend the Panchayat meetings regularly while majority i.e. 54.7 per cent of the total respondents do not attend Panchayat meetings regularly. On being enquired, the respondents reveal contradiction of the viewpoint between the common villagers and the panchayat members. The villagers opined that they are not consulted or their viewpoints are not taken into account at the time of policy implementation. On the other hand panchayat hold that they consult and encourage villagers to participate and extend cooperation to the villagers.

In response to the query, only 20 per cent of the respondents holds that Panchayat members encourage popular participation of villagers while 56 per cent responded that Panchayati members do not encourage popular participation of villagers. On asked about supervision of the works by panchayat, majority of the respondents opined that they are not satisfied with the supervisory function of panchayat. 
TABle Vi Perception On Participation Of Villagers In Panchayat Activities

\begin{tabular}{|l|c|c|c|c|}
\hline \multirow{2}{*}{ Districts } & \multicolumn{2}{|c|}{ Do panchayat members encourage popular participation of villagers? } & \multirow{2}{*}{ Total } \\
\cline { 2 - 4 } & Yes & No & Don't Know & \\
\hline East Siang & $24(12.0 \%)$ & $152(76.0 \%)$ & $24(12.0 \%)$ & $200(100.0 \%)$ \\
\hline Lower Subansiri & $28(14.0 \%)$ & $108(54.0 \%)$ & $64(32.0 \%)$ & $200(100.0 \%)$ \\
\hline West Kameng & $68(34.0 \%)$ & $76(38.0 \%)$ & $56(28.0 \%)$ & $200(100.0 \%)$ \\
\hline Total & $120(20.0 \%)$ & $336(56.0 \%)$ & $144(24.0 \%)$ & $600(100.0 \%)$ \\
\hline
\end{tabular}

TABLE ViI Perception On PaRticipation Of Villagers In IMPLEMENTATION Of SCHEMES

\begin{tabular}{|l|c|c|c|c|}
\hline \multirow{2}{*}{ District } & Do panchayat members consult the villagers at the time of implementation of schemes? & \multirow{2}{*}{ Total } \\
\cline { 2 - 5 } & Yes & No & Don't Know & $200(100.0 \%)$ \\
\hline East Siang & $140(70.0 \%)$ & $32(16.0 \%)$ & $28(14.0 \%)$ & $200(100.0 \%)$ \\
\hline Lower Subansiri & $100(50.0 \%)$ & $56(28.0 \%)$ & $44(22.0 \%)$ & $200(100.0 \%)$ \\
\hline West Kameng & $60(30.0 \%)$ & $96(48.0 \%)$ & $44(22.0 \%)$ & $600(100.0 \%)$ \\
\hline Total & $300(50.0 \%)$ & $184(30.7 \%)$ & $116(19.3 \%)$ & Sour \\
\hline
\end{tabular}

The table reveals that majority i.e. 50 per cent of the respondents responded that Panchayat members consult the villagers at the time of implementation of schemes while 30.7 per cent opined that panchayat members do not consult the villagers at the time of implementation of the schemes. Though quite a good number responded positive, they hold that they attended the meetings of panchayats only when they are invited by the panchayat representatives. The study also reveals lack of coordination among the villagers, panchayat members and government officials in making plan project and implementation of rural development schemes. This position of relationship between the officials, panchayat members and villagers led to creation of rifts instead of goodwill and cooperation.

\section{CONCLUSION}

Panchayati Raj Institutions, as unit of local selfgovernment for rural development facilitated the mechanism of democratic decentralisation and rural development. The institutions serve not only as institutions of political participation but also as institution of socialeconomic development of the rural masses. The evaluation of the data with regard to the awareness of villagers regarding the role of Panchayati Raj Institutions in rural development reveals a positive response. They know the objective with which panchayats are instituted and the work they are to perform as elected representatives at grass root level. However, in response to the query whether panchayat works independently and in the right direction. Majority opined that three tier Panchayats in their districts are not functioning independently and in right directions. This implies non adherence of Panchayati Raj Institutions to the guidelines as envisaged in the $73^{\text {rd }}$ amendment act. This also implies ineffective and inefficient performance compromising accountability, transparency and participatory approach in implementation of rural development programmes. With regard to the participation of villagers in the panchayat meeting, policy initiative and consultation of panchayat to the village or village authorities, the study found a contradiction of view point between the common villagers and panchayat members. The villagers opined that they are not consulted or their views are not taken into account at the time of policy implementation. On the other hand, the panchayat members hold that they consult and encourage the villagers to participate, initiate and extend cooperation to the panchayat bodies. Further, the analysis of the data as revealed in study with regard to their perception on the working of Panchayati Raj institutions, majority of the respondents responded that they are unsatisfied with the working pattern of panchayat bodies. They hold the view that no meaningful developments are taking place in the area and the few works taken up by them do not benefit the targeted group as envisaged. Further, the training and supervision of officials involved in the rural development activities is one of the objectives and tested tools for improvement of performance and up gradation of knowledge skills. However, the study observed lack of adequate training among the panchayat leaders. In brief it can be concluded from the study that most of the works performed by the panchayati raj institutions are largely depending on the power set up of the state. The works are not done in accordance with the guidelines as envisaged under the $73^{\text {rd }}$ constitutional amendment act. Hence, there is a need to look into the lacuna or drawbacks to make panchayati raj system effective and efficient as envisaged in the $73^{\text {rd }}$ Constitutional Amendment Act.

\section{REFERENCES}

[1] Chambers, R. (1983). Rural Development - Putting the Last First. Harlow: Prentice Hall.

[2] Desai, V. (1991). Fundamentals of Rural Development. Rawat 
Publication, New Delhi.

[3] Dubey, S. (2005). Dynamics of Tribal Local Polity and Panchayati Raj in Arunachal Pradesh. Premiere Publishing House, New Delhi.

[4] Elwin, V. (1957). A Philosophy for NEFA. Department of Research, Govt. of Arunachal Pradesh, Shillong.

[5] Elwin, V. (1964). Democracy in NEFA, Department of Research, Govt. of Arunachal Pradesh, Itanagar.

[6] Gyati, A. (2012). Democratic Decentralisation in a Frontier TribeThe Apatanis. Himalayan Publishers and Distributors, Itanagar.

[7] Mishra, A. -K., Akhtar, N., \& Tarika, S. (2011). Role of the Panchayati Raj Institutions in Rural Development (An Analytical Study of Uttar Pradesh), SMS, Vol. 7, No. 1, 44 - 53.

[8] Jalihal, K. A., \& Shivamurthy, M. (2003). Pragmatic Rural Development for Poverty Alleviation: A Pioneering Paradigm. Concept Publishing, New Delhi.

[9] Maheswari, S. R. (2000). Local Government in India. Lakshmi Narain Agarwal, New Delhi.
[10] Swain, P.C. (2008). Panchayati Raj, A.P.H. Publishing Corporation, New Delhi.

[11] Singh, K. (1999). Rural Development: Principles, Policies and Management ( $2^{\text {nd }}$ ed.), Sage Publication, New Delhi.

[12] Thanikasalam, S. \&Saraswathy, S. (2014). Role of Gram Panchayat in RuralDevelopment: A Study of Vagurani Village of Usilampatti Block of Madurai District (Tamil Nadu), International Journal of Humanities and Social Science Invention, Volume 3, Issue 1, 49-56.

[13] Lele, U. (1975). The Design of Rural Development: Lessons from Africa, Baltimore-London (A World Bank Research Publication), John Hopkins University Press.

[14] Mishra, S. N. \& Mishra, M. (2002). Decentralised Governance, Shipra Publications, New Delhi.

[15] Talukdar, A. C. (1987). Political Transition in Grassroots in Tribal India, Omsons Publications, Gauhati. 